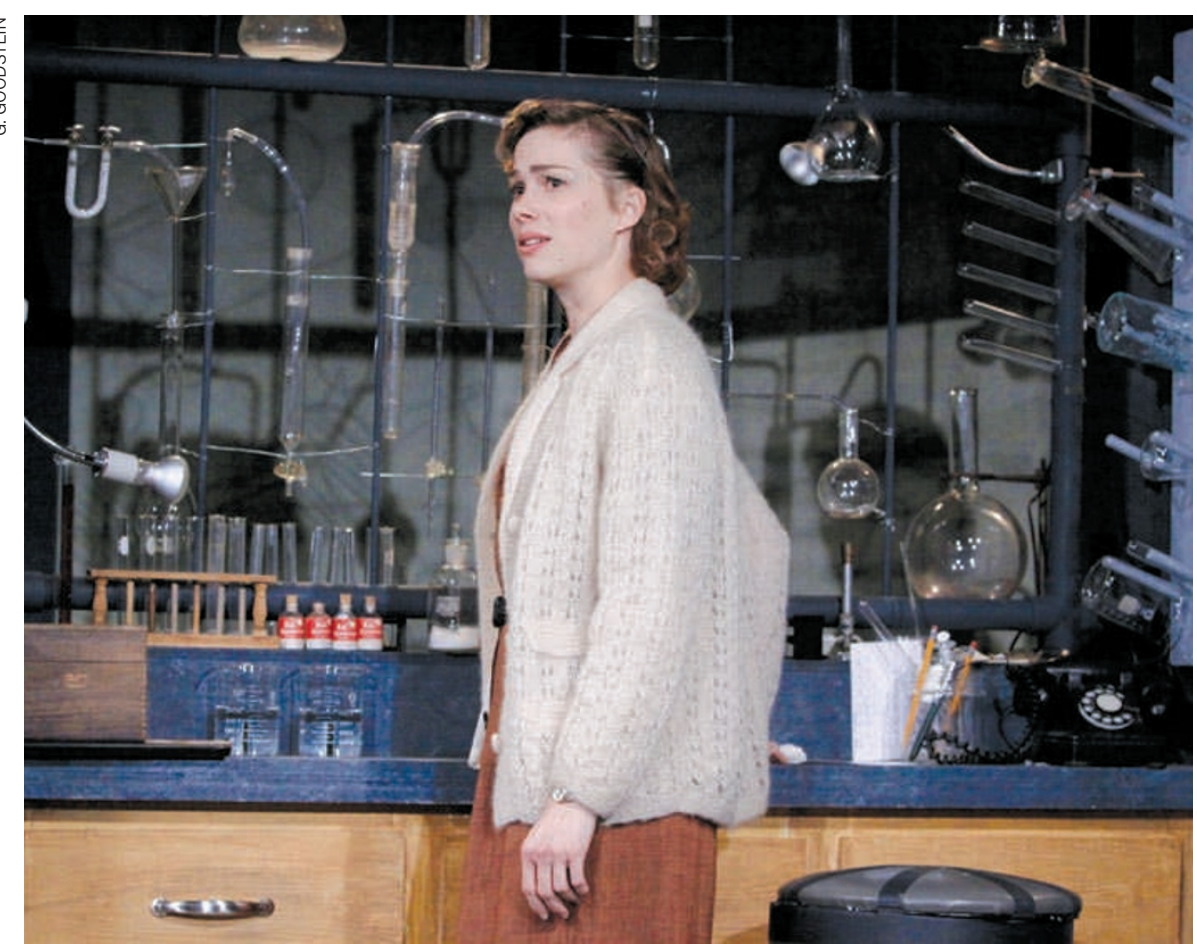

Kristen Bush as Rosalind Franklin in a play about collaboration, competition and pursuing scientific glory.

HISTORY

\title{
Franklin, centre stage
}

\section{Josie Glausiusz enjoys a play capturing the zeal and backstabbing in the race to discover DNA's structure.}

A bell chimes, and a moment of calm descends on the stage, as Rosalind Franklin marvels at an X-ray diffraction image. "It's a perfect X. It's a helix," she says. "I've never seen anything like it."

What Franklin saw that night in May 1952 is at the heart of Anna Ziegler's powerful new play, Photograph 51, funded by the Alfred P. Sloan Foundation and now showing at the Ensemble Studio Theater in Manhattan. Played in plummy tones by Kristen Bush, Franklin is the focus of this fast-paced performance, which dramatizes the obsessive and, at times, devious race to discover the structure of DNA.

Ziegler was originally commissioned by a Maryland theatre, Active Cultures, to create a play about three women scientists, but rewrote the script to focus on Franklin alone after realizing that it was her story that really grabbed her. As a Jewish woman, Franklin was thwarted by obstacles of the time sexism and anti-Semitism - and by her own internal limitations, Ziegler says. Her toughness got her where she was, but it also meant that she guarded her ideas from outside interference. "The play is largely about Franklin's inability to collaborate, or lack of

\section{Photograph 51 WRITTEN BY ANNA ZIEGLER; DIRECTED BY LINSAY FIRMAN. \\ The Ensemble Studio Theatre, New York City. Until 21 November 2010}

desire to," she adds.

The famous Photograph 51 from which the play takes its name is Franklin's best recording of the patterns produced by bouncing X-rays off crystallized molecules of DNA. It was later shown without her knowledge to James Watson, who recognized the helix as the missing piece of the puzzle that enabled him and his collaborator Francis Crick to construct their famous model of the molecule of life. With a cast of characters that includes a wild-haired Watson (played by Haskell King) and a bewildered Maurice Wilkins (Kevin Collins) - Franklin's colleague at King's College London, who revealed the image to Watson - Ziegler has produced a witty and poignant account of the controversy surrounding DNA's discovery.

The play is based on fact, and in large part on Brenda Maddox's moving biography, Rosalind Franklin: The Dark Lady of DNA (HarperCollins, 2002), as well as Watson's best-selling The Double Helix (Atheneum, 1968). Ziegler crams a great deal of complicated science into 90 minutes, capturing both the zeal and the backstabbing that often accompany the pursuit of scientific glory. The compressed format, however, precludes the wealth of detail that appeared in Maddox's biography, which presents Franklin not just as a dedicated scientist but as an elegant and generous young woman with many friends, who loved hiking and travelling.

As in real life, Franklin battles in the play for respect as an accomplished woman scientist in the 1950s. She faces a barrage of belittling rules and remarks, not least from Watson who, as he wrote in The Double Helix, wondered how "Rosy" would look "if she took off her glasses and did something novel with her hair." The characters in the play inform Franklin, like a chorus of bad fairies, that she might have achieved more if she had been more open, less wary, willing to take more risks, make models, move forwards without the certainty of proof. She may have triumphed, they jibe, if she was born at another time - or born a man.

The sexism that Franklin faced in the stifling environment of King's may explain why the playwright depicts her as stubborn, secretive and rarely happy. One of her few moments of serenity comes during an imagined conversation with a close friend, US biophysi-

"She may have triumphed, theyjibe, if she was born at another time - or born aman." cist Don Caspar. Asked what she wants, she replies, "So many things: to wake up without feeling the weight of the day pressing down ... to eat more beets and also turnips, to be kissed ... be a child again, held up and admired, the world full of endless future."

Alas, Franklin's future was cut short by ovarian cancer, from which she died in 1958. Although not covered by the play, she had moved in 1953 to Birkbeck College, now part of the University of London, where she worked happily on the structure of tobacco mosaic virus. Because the Nobel prize is not awarded posthumously, she did not share in the 1962 prize in physiology or medicine that was awarded to Watson, Crick and Wilkins. But as Ziegler conveys, it is not clear that she was fixated on the prize, although no doubt she would have been happy to win it.

"She was more about the work and the process, and not as much about the accolades," Ziegler says. "It was about the personal satisfaction of understanding and cracking something. She was in a different kind of race." -

Josie Glausiusz is a journalist based in New York and a contributor to the science blog www.lastwordonnothing.com. 